\title{
THE EFFECT OF HUMIC-FATTY ACID PREPARATION ON PRODUCTION PARAMETERS AND MEAT QUALITY OF GROWING RABBITS
}

\author{
Dorota Miśta ${ }^{1}$, Anna Rząsa ${ }^{2}$, Tadeusz Szmańko ${ }^{3}$, Wojciech Zawadzki ${ }^{1}$, \\ Marzena Styczýnska ${ }^{4}$, Anna Pintal ${ }^{3}$, Bożena Króliczewska ${ }^{1}$ \\ ${ }^{1}$ Department of Biostructure and Animal Physiology, Wroclaw University of Environmental \\ and Life Sciences, Norwida 31, 50-375 Wrocław, Poland \\ ${ }^{2}$ Department of Immunology, Pathophysiology and Veterinary Prevention, Wroclaw University \\ of Environmental and Life Sciences, Norwida 31, 50-375 Wrocław, Poland \\ ${ }^{3}$ Department of Animal Product Technology and Quality Management, Faculty of Food Science, Wro- \\ claw University of Environmental and Life Sciences, Chełmońskiego 37/41, \\ 51-630 Wrocław, Poland \\ ${ }^{4}$ Department of Human Nutrition, Wroclaw University of Environmental and Life Sciences, \\ Chełmońskiego 37/41, 51-630 Wrocław, Poland
}

\begin{abstract}
The aim of the study was to determine the effect of a humic-fatty acid preparation on production parameters and meat quality of rabbits. Three groups of New Zealand White rabbits were used (one control and two experimental) with 8 animals per group. The animals of group $\mathbf{C}$ (control) were fed standard pelleted diet, group $\mathrm{H5}$ received a control diet supplemented with $5 \%$, and group $\mathrm{H10}$ a control diet with $\mathbf{1 0 \%}$ humic-fatty acid preparation. The experiment was terminated after 6 weeks feeding, when rabbits were slaughtered. The experimental groups showed higher gains and a higher feed conversion ratio than the control group. The dietary inclusion of the experimental additive had a beneficial effect on the meat quality traits, such as Fe concentration, hardness and colour, but it also increased the susceptibility of fat to oxidative changes.
\end{abstract}

Key words: rabbit, humic-fatty acid preparation, meat, fat, rearing results

In recent years, there is growing interest in the use of humic compounds in animal feeding. They can be components of various preparations and seem to be interesting feed additives, especially when produced with the addition of vegetable oils (Gładkowski et al., 2011; Pisarikova et al., 2010). The effect of humic compounds used in animal nutrition on rearing performance improved the results obtained for growth rate, feed utilization, meat quality, egg yield, and egg shell thickness and strength (Agazzi et al., 2007; Dobrzański et al., 2009; Karaoglu et al., 2004; Rath et al., 2006; Wang et al., 2008). 
No study on the use of humic compounds in rabbit nutrition has been undertaken so far. The high nutritional value and the outstanding taste of rabbit meat have given rise to an increase in its consumption in a number of countries (Dalle Zotte, 2002; Pogány Simonová et al., 2010). This means that the search for the new ways to improve the production yield of this animal species is of considerable interest. The humic-fatty acid preparation used in this study is a mixture of vegetable oils on a humic-mineral carrier. Among other types, the raw materials like peat, humodetrinite, dolomite or bentonite were used to prepare this additive (Dobrzański et al., 2009). The rich composition of this preparation, which has been used for poultry, cattle and pigs, seems also to comply with rabbits' nutritional requirements. It contains about 40 minerals, including the most important macro- and microelements for the rabbits' diet. Additionally, the vegetable oils used as components of the preparation are rich in unsaturated fatty acids that benefit the fatty acid profile of the meat (Corino et al., 2002).

In the present study, we assessed the effect of humic-fatty acid preparation on production parameters as well as on meat quality indices of growing rabbits.

\section{Material and methods}

The research material consisted of 24 New Zealand White rabbits aged 2 months, fed ad libitum with a standard commercial feed for fast-growing rabbits, according to the recommendations given in the international feeding standards (De Blas and Wiseman, 1998). The animals were kept under vivarium conditions in underslung grate cages, with 4 individuals in each cage. They had free access to drinking water. The experiment was performed after approval from the Local Ethics Commission for Experiments on Animals in Wroclaw, Poland (license no. 78/2007).

After a 3-week adaptation period, the rabbits were divided according to the analogue rule (based on sex and body weight) into 3 groups, with 8 individuals per group: group $\mathrm{C}$ (control) consisted of animals given the basal diet without any additive, group $\mathrm{H} 5$ consisted of animals given the basal diet with a 5\% humic-fatty acid preparation (w/w) and group $\mathrm{H} 10$ consisted of animals given the basal diet with a $10 \%$ humic-fatty acid preparation (w/w). The composition of the basal feed mixture is presented in Table 1. The humic-fatty acid preparation (Humobentofet, Tronina PHW, Poland) was composed of $80 \%$ humic-mineral carrier and $20 \%$ vegetable oils (48\% oleic, 20\% linoleic, 5\% linolenic and 15\% palmitic acid), which caused its energy value to be $8 \mathrm{MJ} / \mathrm{kg}$. The main mineral components of this preparation were (g/kg of preparation dry matter): $\mathrm{Si}(228.9), \mathrm{Al} 2 \mathrm{O} 3$ (69.0), $\mathrm{Fe}(2.25), \mathrm{Ca}(3.03), \mathrm{Na}$ (2.2), Mg (3.3), P (6.6), Mn (0.08), Zn (0.04), Cu (0.006), K (0.003), Co (0.002), Se (0.0001). The experiment lasted for 6 weeks. During this feeding period, the body weight of the animals and their feed consumption were assessed once a week, and the weekly body gain and the ratio of gain to feed consumption (feed conversion ratio) were calculated. 
Table 1. The composition and nutritional values of the basal feed mixture

Ingredients:

\begin{tabular}{lc} 
dried grass (\%) & 13 \\
dried alfalfa (\%) & 15 \\
wheat bran (\%) & 17 \\
wheat grain (\%) & 10 \\
barley grain (\%) & 10 \\
corn (\%) & 15 \\
extracted soybean meal (\%) & 10 \\
rape meal (\%) & 5 \\
rapeseed oil (\%) & 1 \\
vitamin-mineral premix ${ }^{1}(\%)$ & 4 \\
crude protein (\%) & \\
crude fat (\%) & 17.00 \\
crude fibre (\%) & 3.60 \\
crude ash (\%) & 11.80 \\
nitrogen free extract (\%) & 5.50 \\
starch (\%) & 47.60 \\
soluble sugars (\%) & 21.50 \\
metabolizable energy (MJ/kg) & 7.40 \\
linoleic acid (\%) & 10.95 \\
linolenic acid (\%) & 0.46 \\
calcium (\%) & 0.09 \\
phosphorus (\%) & 0.95 \\
sodicum (\%) & 0.45 \\
chlorine (\%) & 0.15 \\
potassium (\%) & 0.40 \\
magnesium (\%) & 1.65 \\
\hline & 0.43 \\
\hline
\end{tabular}

${ }^{1}$ Premix provided per $\mathrm{kg}$ of diet: vitamin $\mathrm{A}, 15000 \mathrm{IU}$; vitamin $\mathrm{D}_{3}, 1504.0 \mathrm{IU}$; vitamin $\mathrm{B}_{1}, 8.7 \mathrm{mg}$; vitamin $\mathrm{B}_{2}, 13.1 \mathrm{mg}$; vitamin $\mathrm{B}_{6}, 7.1 \mathrm{mg}$; vitamin $\mathrm{B}_{12}, 0.01 \mathrm{mg}$; vitamin $\mathrm{E}, 57.2 \mathrm{mg}$; vitamin $\mathrm{C}$, $73 \mathrm{mg}$; vitamin $\mathrm{K}$, $39.9 \mathrm{mg}$; folic acid, $1.7 \mathrm{mg}$; niacin, $63.10 \mathrm{mg}$; pantothenic acid, $30.1 \mathrm{mg}$; choline $884 \mathrm{mg}$; inositol, $1334 \mathrm{mg}$; biotin, $0.272 \mathrm{mg}$; Mn, $80 \mathrm{mg}$; Cu, $15 \mathrm{mg}$; Fe, $197 \mathrm{mg}$; Zn, $62 \mathrm{mg}$; Co $0.523 \mathrm{mg}$; iodine, $0.638 \mathrm{mg}$; Se, $0.157 \mathrm{mg}$; F, $0.032 \mathrm{mg}$.

At the end of the experiment, the rabbits were slaughtered, and samples of the longissimus dorsi were removed for the estimation of the meat and fat quality. The $\mathrm{pH}$ values were determined using a Microcomputer CP-551, according to Polish Standard PN-ISO 2917 (2001). The protein content of the meat was determined using the Kjeldahl method according to Polish Standard PN-75/A 04018 (1975) and intramuscular fat by the Soxhlet method, according to PN-ISO 1444 (2000). The iron content of the meat was determined by atomic absorption spectrophotometry (AAS) according to Polish Standard PN-EN 13805 (2003). Sample mineralization was assessed according to Polish Standard PN-EN 14084 (2004). The water holding capacity (WHC) was evaluated using the Grau-Hamm method with the modification of Szmańko (1986). It was estimated based on the percentage of water remaining in $300 \mathrm{mg}$ of the sample subjected to $2-\mathrm{kg}$ pressure for 5 minutes on a Whatman No. 1. The hardness of the meat was measured on a Zwick/Roell Z010 texture meter via 
the penetrometric method. The sensory evaluation of the meat and fat was performed according to a 5-points scale (PN-ISO 6658 1998). A test panel consisting of five people judged the meat samples for their colour, smell, tenderness and external appearance. Whole samples of meat without any additives (salt or spice) were placed in an electric oven preheated to $180^{\circ} \mathrm{C}$, until an internal temperature of $80^{\circ} \mathrm{C}$ was reached. Samples were served individually to each of the trained panelists in hermetic plastic containers immediately after roasting. A 5-point scale was used: $1=$ very disagreeable; 2 = moderately disagreeable; 3 = slightly agreeable; 4 = agreeable; $5=$ very agreeable (Cross et al., 1986).

The freezing point of the fat was determined according to Polish Standard PN-C 04508 (1984). Lipid oxidation was measured using the modified Salih method with 2-thiobarbituric acid (TBA).

The results of the study were analysed statistically using Statistica 7.1 software (Statistica for Windows, StatSoft, Tulsa, OK, USA). The one-factorial analysis of variance (ANOVA) was used with the level of significance set at $\mathrm{P}<0.05$. The significance of differences was confirmed by means of Tukey's multiple comparison test.

\section{Results}

Initial and final body weight as well as weight gain, feed intake and weight gain to feed intake ratio calculated weekly and for the experimental period are presented in Table 2. There were no statistical differences between all analysed production parameters. However, it was observed that in groups of rabbits fed diets supplemented with the humic-fatty acid preparation (H5 and H10) the body weight gains tended to increase (130.6 $\mathrm{g}$ and $132.9 \mathrm{~g}$, respectively) as compared to the control group (108.9 g). Simultaneously, in group H5 the lowest weekly feed intake was noted compared to the other groups. The calculated ratio of body weight gain to feed intake proved to be higher in the experimental groups (H5 and $\mathrm{H} 10 ; 0.16$ and 0.15 , respectively) than in the control group (0.13), and the highest index was noted for group H5. The same tendency was found for the whole feeding period.

Table 3 presents the investigated quality traits of the meat and fat. An increase in the $\mathrm{pH}_{24}$ value was observed in group $\mathrm{H} 10(\mathrm{P}<0.05)$. A slightly decreasing tendency in the protein content of the same group was noted. The humic-fatty acid additive had no effect on the content of intramuscular fat which ranged from 1.78 (H5) to 2.26 (control group). Moreover, the iron concentration was significantly higher in H10 $(0.572 \mathrm{mg} / 100 \mathrm{~g})$ compared to the control group $(0.544 \mathrm{mg} / 100 \mathrm{~g})$ (Table 3$)$. The humic-fatty acid preparation also induced favourable changes in such an important parameter as hardness, which decreased by $32 \%$ in group $\mathrm{H} 10$ in comparison to the control group $(\mathrm{P}<0.05)$. A slight increasing tendency in WHC value was observed for the same group. Some beneficial effects of this preparation on the sensory properties of the meat and fat were observed. A slight improvement in the colour of meat, but significant in the colour of fat $(\mathrm{P}<0.05)$, and a slight tendency towards a better meat flavour and tenderness were obtained. The additive had a non-significant influence on the freezing point of fat: in group H10, this parameter was slightly lower 
than in groups $\mathrm{C}$ and $\mathrm{H} 5$. On the other hand, there was an increase in susceptibility to lipid oxidation in group H10, especially in meat stored for 72 hours $(\mathrm{P}<0.05)$.

Table 2. The production parameters of the rabbits $(n=8)$

\begin{tabular}{|c|c|c|c|}
\hline \multirow{2}{*}{ Item } & \multicolumn{3}{|c|}{ Group } \\
\hline & $\mathrm{C}$ & $\mathrm{H} 5$ & $\mathrm{H} 10$ \\
\hline Initial body weight $(\mathrm{g})$ & $2464 \pm 223$ & $2473 \pm 297$ & $2437 \pm 409$ \\
\hline Final body weight (g) & $3118 \pm 218$ & $3256 \pm 260$ & $3235 \pm 501$ \\
\hline Weekly body weight gain (g/animal) & $108.9 \pm 19.8$ & $130.6 \pm 31.0$ & $132.9 \pm 52.0$ \\
\hline Weekly feed intake (g/animal) & $892.4 \pm 42.0$ & $873.1 \pm 165.6$ & $938.3 \pm 106.2$ \\
\hline Weekly body weight gain/feed intake & $0.13 \pm 0.02$ & $0.16 \pm 0.06$ & $0.15 \pm 0.05$ \\
\hline $\begin{array}{l}\text { Body weight gain during the whole experiment } \\
\text { (g/animal) }\end{array}$ & 653.4 & 783.5 & 797.3 \\
\hline Feed intake during the whole experiment (g/animal) & 4462.2 & 4365.5 & 4691.3 \\
\hline $\begin{array}{l}\text { Body weight gain/feed intake during the whole } \\
\text { experiment }\end{array}$ & 0.15 & 0.18 & 0.17 \\
\hline
\end{tabular}

$\mathrm{C}$ - animals fed the basal diet (control), H5 - animals fed the basal diet with a 5\% humic-fatty acid additive, $\mathrm{H} 10$ - animals fed the basal diet with a $10 \%$ humic-fatty acid additive.

The results are expressed as the mean $\pm \mathrm{SD}$.

Table 3. The selected quality traits of the rabbit meat and fat $(n=8)$

\begin{tabular}{|c|c|c|c|}
\hline \multirow{2}{*}{ Item } & \multicolumn{3}{|c|}{ Group } \\
\hline & $\mathrm{C}$ & H5 & H10 \\
\hline \multicolumn{4}{|l|}{ Meat: } \\
\hline $\mathrm{pH}_{24}$ & $5.45 \mathrm{a} \pm 0.13$ & $5.41 \mathrm{a} \pm 0.04$ & $5.58 \mathrm{~b} \pm 0.15$ \\
\hline total protein $(\%)$ & $25.06 \pm 0.72$ & $25.26 \pm 0.19$ & $24.68 \pm 0.48$ \\
\hline intramuscular fat (\%) & $2.26 \pm 0.45$ & $1.78 \pm 0.62$ & $1.91 \pm 0.51$ \\
\hline $\mathrm{Fe}(\mathrm{mg} / 100 \mathrm{~g}$ meat $)$ & $0.544 \mathrm{a} \pm 0.130$ & $0.543 \mathrm{a} \pm 0.020$ & $0.572 b \pm 0.140$ \\
\hline water holding capacity (\%) & $55.39 \pm 0.74$ & $55.77 \pm 1.58$ & $58.01 \pm 1.85$ \\
\hline hardness $(\mathrm{N})$ & $3.46 \mathrm{a} \pm 0.36$ & $3.24 \mathrm{a} \pm 0.25$ & $2.36 \mathrm{~b} \pm 0.26$ \\
\hline \multicolumn{4}{|l|}{ sensory score (points): } \\
\hline external appearance & $4.7 \pm 0.2$ & $4.6 \pm 0.2$ & $4.8 \pm 0.2$ \\
\hline colour (intensity) & $4.0 \pm 0.2$ & $4.3 \pm 0.1$ & $4.4 \pm 0.2$ \\
\hline colour (desirability) & $4.5 \pm 0.3$ & $4.7 \pm 0.2$ & $4.7 \pm 02$ \\
\hline smell (intensity) & $4.5 \pm 0.3$ & $4.5 \pm 02$ & $4.6 \pm 0.2$ \\
\hline tenderness & $4.4 \pm 0.5$ & $4.7 \pm 0.1$ & $4.5 \pm 0.3$ \\
\hline \multicolumn{4}{|l|}{ Fat: } \\
\hline freezing point $\left({ }^{\circ} \mathrm{C}\right)$ & $24.2 \pm 1.2$ & $24.49 \pm 0.9$ & $23.6 \pm 0.7$ \\
\hline colour sensory score (points) & $3.8 \mathrm{a} \pm 0.1$ & $4.3 b \pm 0.3$ & $5.0 \mathrm{c} \pm 0.1$ \\
\hline \multicolumn{4}{|l|}{$\mathrm{TBA}^{*}$} \\
\hline after $6 \mathrm{~h}$ & $8.4 \mathrm{a} \pm 0.2$ & $6.9 \mathrm{~b} \pm 0.5$ & $9.9 \mathrm{c} \pm 0.2$ \\
\hline after $24 \mathrm{~h}$ & $10.3 \mathrm{a} \pm 1.1$ & $8.6 \mathrm{~b} \pm 0.2$ & $10.0 \mathrm{a} \pm 0.4$ \\
\hline after $72 \mathrm{~h}$ & $12.5 \mathrm{a} \pm 3.4$ & $17.4 b \pm 2.5$ & $19.1 b \pm 0.4$ \\
\hline
\end{tabular}

$\mathrm{C}$ - animals fed the basal diet (control), H5 - animals fed the basal diet with a 5\% humic-fatty acid additive, $\mathrm{H} 10$ - animals fed the basal diet with a $10 \%$ humic-fatty acid additive.

* $\mu$ g malonyldialdehyde/g fat.

The results are expressed as the mean $\pm \mathrm{SD}$.

$\mathrm{a}, \mathrm{b}, \mathrm{c}-$ values in rows with different letters differ significantly at $\mathrm{P}<0.05$. 


\section{Discussion}

The authors of most papers on the application of humic additives in animal feed report that they have a positive influence on body weight gains. Such results were obtained in a study with pigs by Wang et al. (2008), who also showed a beneficial increase in the ratio of body weight gain to feed intake. The same tendency was also noted in this study. Similar results were obtained for poultry where these substances resulted in higher body weight gains (Karaoglu et al., 2004). However, other authors did not observe any differences in the daily weight gains in chickens that were given humic acids (Herzig et al., 2009). Rath et al. (2006) reported a decrease in the body weight gains in broiler chickens under the influence of humic acid (HA), but at the same time, they noted an improvement in feed utilization. However, the authors of that last study used small HA supplements of 0.5 to $2.5 \%$.

The addition of humic compounds to milk that was given to young goats caused an increase in the body weight gains (Agazzi et al., 2007). The authors of that study suggested that the increase in gains may be the result of an increased cellular response, and better nutrient absorption, caused by the antidiarrhoeal activity of the humic compounds. According to Huck et al. (1991), the increase in body weight gains in animals may be influenced by the antibacterial and antiviral properties of humic compounds, which influence the maintenance of bacterial flora homeostasis, and thus the state of intestinal health. Therefore, the increased body weight gains in animals fed the humic-fatty acid additive may result from its influence on the metabolism of microflora colonizing the caecum. An in vitro study showed that this additive caused an increase in the percentage contribution of propionic acid to the overall pool of volatile fatty acids created by the microflora of the intestines (Miśta, 2007), and this acid is a very effective substrate in glucose synthesis, and takes part in glycogenesis and in the formation of long-chain fatty acids. Moreover, the propionate enhances iron absorption in the proximal colon (Bougle et al., 2002).

The unsaturated fatty acids included in the analysed humic-fatty acid additive might also have been the reason for the increase in the body weight gains in rabbits from the experimental groups. Partridge et al. (1986), who analysed the addition of 6 and $10 \%$ fat in the form of soybeans or animal fat to the feed of growing rabbits observed a small improvement in daily weight gains and feed utilization. An improvement in feed utilization (feed/gain ratio) in rabbits thanks to the addition of plant fats was also observed by Fernández and Fraga (1996).

Many authors showed the effect of diet on meat quality and blood parameters of rabbits (Bielański et al., 2007; Cygan-Szczegielniak et al., 2010; Dalle Zotte et al., 1996; Pogány Simonová et al., 2010; Stasiak et al., 2010). One of the most important parameters that influenced meat quality is changes in the $\mathrm{pH}$ value after slaughter. This parameter determines meat properties necessary to obtain a final product for utilization by the food industry. Rabbit meat is characterized by a higher $\mathrm{pH}$ value than that of other species, and this negatively influences its shelf-life. The increasing influence of a $10 \%$ humic-fatty acid additive on $\mathrm{pH}_{24}$ was observed in the present study. In this study, the $\mathrm{pH}$ was between 5.41 and 5.58, which is a higher result than that observed by Corino et al. (2007) in New Zealand White rabbits. They re- 
ported values of 5.10-5.16 in the longissimus lumborum, while Barròn et al. (2004) estimated 6.3 in the longissimus dorsi and 6.2 in the biceps femoris. These authors observed $\mathrm{pH}$ differentiation between genotypes and gender, and the values for the New Zealand Whites were the highest. Dal Bosco et al. (2002) found higher $\mathrm{pH}_{24}$ values in the longissimus lumborum of hybrid rabbits, in the range between 5.66 and 5.86. Previous studies showed the positive effect of dietary humate supplementation on decreasing meat $\mathrm{pH}$ in different species (Aksu et al., 2005; Esenbuğa et al., 2008) in opposition to our results. The results obtained could be explained as the effect of the other components of this preparation.

The relatively high protein content in rabbit meat (18.1-23.7\%) compared to pork (17.2-19.9\%) and chicken (17.9-22.2\%) testifies to the high quality of this product (Dalle Zotte, 2002; Salvini et al., 1998). Moreover, according to data obtained by Szkucik and Libelt (2006) the protein level in rabbit meat depends on part of carcass. The lowest level of protein content is found in the front of the carcass $(21 \%)$, higher in the thigh $(22.8 \%)$ and the highest in the saddle meat $(23.9 \%)$. A relatively high protein level in the investigated meat samples was obtained in the present study as compared to other authors. In this study, the average level was $25 \%$. A slightly lower level of this parameter compared to the analysed study was shown in the same breed of rabbit $(23.3 \%)$ by Corino et al. (2007) and in the crossbreds $(22.2-23.6 \%)$ by Cygan-Szczegielniak et al. (2010).

Rabbit meat is regarded as a low-fat meat with the concentration of lipids varying typically from 1 to $6 \%$ according to carcass part (Szkucik and Libelt, 2006). Between individual muscles, the fat content varies typically from $1-2 \%$ in the longisssimus dorsi muscle to $3-4 \%$ in the hind leg (Dalle Zotte et al., 1996). The values obtained in $l$. dorsi in the present study are similar to the results reported by Króliczewska et al. (2011) for the same breed of rabbit (1.78 to 2.11\%), and by Maj et al. (2006) in Castorex rabbits (1.58 to $1.83 \%$ ). Slightly lower values were obtained by Cygan-Szczegielniak et al. (2010) in crossbreds (1.31-1.47\%). Dietary fat inclusion level and source play a role in carcass and meat quality. When higher fat inclusions in the diet are carried out, the fat content of the meat increases, while protein content decreases (Dalle Zotte, 2002; Pla and Cervera, 1997). In our study, the supplementation with humic-fatty acid preparation had no effect on the level of intramuscular fat and did not increase the fat:protein ratio, which ranged from 0.07 in $\mathrm{H} 5$ to 0.09 in the control group.

Two of the richest sources of iron in the human diet are meat and egg yolk. Thus, a humic-fatty acid additive increasing the iron level in the serum and meat could be regarded as one of the most important benefits of using dietary humic substance. Hermida et al. (2006) reported that the iron content in the meat of 3-month-old rabbits ranged between 3.77 and $9.11 \mathrm{mg} / \mathrm{kg}$ and the results obtained in this study are within this range. This is quite a satisfactory level compared to that reported by other authors (Dal Bosco et al., 2002).

It is obviously known that WHC is a very important parameter in terms of the meat quality traits. In this experiment, using humic substances was found to be profitable in this regard. It could be effective for some sensory traits like juiciness and hardness. The hardness changes found under the influence of this additive confirm 
the tendency observed in the WHC. The results obtained were negatively correlated with the WHC, confirming previous observations (Szmańko et al., 2007).

Meat sensory estimation is very important for the consumer's choice. The evaluated parameters, especially colour, showed the same tendency to improvement as WHC and hardness under the influence of the humic-fatty acid additive. Wang et al. (2008) reported greater meat redness from pigs fed humic acid, which indicates that such feed supplementation may be associated with meat colour. This improving effect on meat colour was observed also by Esenbuğa et al. (2008) in chickens. Some authors suggest that the reason for the improvement in meat colour due to humic substances could be the content of several minerals ( $\mathrm{Fe}, \mathrm{Mn}, \mathrm{Cu}$ ) or their positive influence on the myoglobin synthesis rate (Wang et al., 2008).

The humic-fatty acid feed additive used in this research did not influence the freezing point of the fat. The tendency observed in group H10 to lowering the value of this point could be due to a higher degree of unsaturation of the fat. The unfavourable effect of this addition on the oxidative processes in the fat was noted based on TBA. It could be explained by the higher iron content in the meat, which catalyzes lipid oxidation (Faustman et al., 2010). The higher unsaturated fatty acid content due to the humic-fatty acid additive could also be the reason for this effect. It could not really be caused by the addition of humic substances. Previous research shows their beneficial influence on lowering lipid oxidation in chicken meat (Aksu et al., 2005). Other authors found a negative effect of dietary fat addition on hepatic, renal, and cerebral TBA-RS concentrations in mice, which confirmed our thesis (Folmer et al., 2003). This negative effect could be eliminated by dietary supplementation of a natural antioxidant, e.g. vitamin E (Bielański et al., 2007; Corino et al., 2007). Despite the higher susceptibility to lipid oxidation, the previously described beneficial effects of a humic-fatty acid additive on rabbit meat indicate that there are grounds to continue the research into its application for rabbit nutrition.

Summing up, the investigated preparation improved some parameters of meat quality, such as iron content, colour, hardness and WHC values, but caused a higher susceptibility to lipid oxidation. Moreover, we observed an improving tendency in the body gains of animals as well as the ratio of gain to feed intake during the experiment. This data may indicate that the application of the humic-fatty acid preparation in the nutrition of growing rabbits will profitably affect the meat quality and the rearing results of these animals.

\section{References}

A gazzi A., Cigalino G., Manc in G., S avoini G., D e 11 ' O r to V. (2007). Effects of dietary humates on growth and an aspect of cell-mediated immune response in newborn kids. Small Ruminant Res., 72: 242-245.

A k s u M.I., K a ra oğ lu M., K a y a M., E s e n buğ a N., M a c it M. (2005). Effect of dietary humate on the $\mathrm{pH}$, TBARS and microbiological properties of vacuum and aerobic-packed breast and drumstick meats of broilers. J. Sci. Food Agric., 85: 1485-1491.

B arròn G., Rosas G., S andoval Ch., B onilla O., Reyes G., Ri c o P., Cardona L., $\mathrm{Z}$ a mor a F. (2004). Effect of genotype and sex on $\mathrm{pH}$ of biceps femoris and longissimus dor- 
si muscles in rabbit carcasses. In: Proceedings - 8th World Rabbit Congress, Puebla, Mexico, pp. 1349-1353.

B i elański P., Kowalska D., Piórkowska M. (2007). Effect of supplemental linseed and antioxidant in rabbit diet on fatty acid profile and susceptibility of meat lipids to oxidation. Pol. J. Nat. Sci., Suppl., 4: 7-12.

B ougle D., Vaghefi- Va ezzaad eh N., Roland N., B ouvard G., Arhan P., Bureau F., $\mathrm{N} \mathrm{e} \mathrm{u} \mathrm{ville} \mathrm{D.,} \mathrm{M} \mathrm{a} \mathrm{u} \mathrm{b} \mathrm{o} \mathrm{is} \mathrm{J.L.} \mathrm{(2002).} \mathrm{Influence} \mathrm{of} \mathrm{short-chain} \mathrm{fatty} \mathrm{acids} \mathrm{on} \mathrm{iron} \mathrm{absorption} \mathrm{by}$ proximal colon. Scand. J. Gastroenterol., 37: 1008-1011.

Corino C., Mourot J., Magni S., Pas torelli G., Ros s i F. (2002). Influence of dietary conjugated linoleic acid on growth, meat quality, lipogenesis, plasma leptin and physiological variables of lipid metabolism in rabbits. J. Anim. Sci., 80: 1020-1028.

Corino C., Lo Fiego D.P., Macchioni P., Pastorelli G., Di Giancamillo A., D o m e n e g h i n i C., R o s s i F. (2007). Influence of dietary conjugated linoleic acids and vitamin E on meat quality, and adipose tissue in rabbits. Meat Sci., 76: 19-28.

Cros s H.R., D u rland P.R., S e i d e m a n S.C. (1986). Sensory qualities of meat. In: Bechtel P.J. (ed.) Muscle as Food. Academic Press, New York, USA, pp. 279-329.

Cygan-Szczegielniak D., Stasiak K., Janicki B. (2010). Effect of diet on selected parameters of post-slaughter carcass evaluation and meat quality of rabbits. Med. Wet., 66: $839-842$.

Dal B os co A., Castellin i C., Mugnai C. (2002). Rearing rabbits on wire net floor or straw litter: behavior, growth and meat qualitative traits. Livest. Prod. Sci., 75: 149-156.

Dalle Z ot te A. (2002). Perception of rabbit meat quality and major factors influencing the rabbit carcass and meat quality. Livest. Prod. Sci., 75: 11-32.

Dalle Zotte A., Ouhayoun J., Parigi Bini R., Xiccato G. (1996). Effect of age, diet and sex on muscle energy metabolism and on related physicochemical traits in the rabbit. Meat Sci., 43: 15-24.

D e B l a s C., W is e m a n J. (1998). Editors. The Nutrition of the Rabbits. Wallingford, U.K., CABI Publishing, 344 pp.

Dobrzański Z., Trziszka T., Herbut E., Krawczyk J., Tronina P. (2009). Effect of humic preparations on productivity and traits of eggs from Greenleg Partridge hens. Ann. Anim. Sci., 9: 165-174.

E s e n bu ğa N., Ma c i t M., Kara o ğlu M., A k s u M.I., Bilg in O.C. (2008). Effects of dietary humate supplementation to broilers on performance, slaughter, carcass and meat colour. J. Sci. Food Agric., 88: 1201-1207.

F a u s t m a n C., S u n Q., M a n c in i R., S u m a n S.P. (2010). Myoglobin and lipid oxidation interactions: Mechanistic bases and control. Meat Sci., 86: 86-94.

F e r ná n d e z C., F r a g a M.J. (1996). The effect of dietary fat inclusion on growth, carcass characteristics, and chemical composition of rabbits. J. Anim. Sci., 74: 2088-2094.

F o l m e r V., S o ares J.C.M., G a briel D., R o ch a J.B.T. (2003). A high fat diet inhibits $\delta$-aminolevulinate dehydratase and increases lipid peroxidation in mice (Mus musculus). J. Nutr., 133: 2165-2170.

Gładkowski W., Kiełbowicz G., Chojnacka A., Gil M., Trziszka T., Dobrzańs k i Z., W a wrzeńc zy k C. (2011). Fatty acid composition of egg yolk phospholipid fractions following feed supplementation of Lohmann Brown hens with humic-fat preparations. Food Chem., 126: $1013-1018$.

Hermida M., Gonza lez M., M irand a M., R odr 1' guez-O te ro J.L. (2006). Mineral analysis in rabbit meat from Galicia (NW Spain). Meat Sci., 73: 635-639.

Herzig I., Navratilova M., T ot u sek J., S u chy P., Vecerek V., B lahova J., Zraly Z. (2009). The effect of humic acid on zinc accumulation in chicken broiler tissues. Czech J. Anim. Sci., 54: 121-127.

Huck J.A., P orter N., B u s hed M.E. (1991). Effect of humates on microbial activity. J. Gen. Microbiol., 137: 2321-2329.

Karaoglu M., Macit M., Es enboga N., Durdag H., Turgut L., Bilgin O.C. (2004). Effect of supplemental humate at different levels on the growth performance, slaughter and carcass traits of broilers. Int. J. Poultry Sci., 3: 406-410. 
Króliczewska B., Miśta D., Z awadzki W., Skiba T. (2011). Effect of baical skullcap root (Scutellaria baicalensis radix) on cholesterol level and meat quality in rabbits fed cholesterol rich diet. Folia Biol. (Krakow) 59: 169-173.

M a j D., Ł a pa P., B i en i ek J., B a rabas z B., W ę g l ar z A. (2006). Characteristics of meat quality in Castorex rabbits (in Polish). Rocz. Inst. Przem. Mięsn. Tł., 44: 73-82.

M is t a D. (2007). The effect of dietary supplement - Humobentofet on rabbit caecal parameters of microbial fermentation at in vitro study. EJPAU, http://www.ejpau.media.pl/volume10/issue4/art13.html.

Partridge G.G., Findla y M., Fordy c e R.A. (1986). Fat supplementation of diets for growing rabbits. Anim. Feed Sci. Technol., 16: 109-118.

P is arikova B., Zraly Z., Herzig I. (2010). The effect of dietary sodium humate supplementation on nutrient digestibility in growing pigs. Acta Vet. Brno, 79: 349-353.

P 1 a M., C e rver a C. (1997). Carcass and meat quality of rabbits given diets having high level of vegetable or animal fat. Anim. Sci., 65: 299-303.

Pogány Simonová M., Chrastinová L., Mojto J., Lauková A., Szabóová R., Raf a y J. (2010). Quality of rabbit meat and phyto-additives. Czech J. Food Sci., 28: 161-167.

R a th N.C., H u ff W.E., H u ff G.R. (2006). Effects of humic acid on broiler chickens. Poultry Sci., 85: 410-414.

Salvini S., Parpinel M., Gnagnarella P., Maisonneuve P., Turrini A. (1998). Editors. Banca dati di composizione degli alimenti per studi epidemiologici in Italia. Istituto Europeo di Oncologia, Milano, Italy, $958 \mathrm{pp}$.

S t a s i k K., C y ga n-S z c z e g i e ln i a k D., J a n i cki B. (2010). Influence of diet on biochemical parameters of rabbits' blood. Med. Wet., 66: 410-412.

S z k u cik K., Libelt K. (2006). Nutritional value of rabbit meat. Med. Wet., 62: 108-110.

S z m a ń k o T. (1986). The equipment used for measurement of water holding capacity. Poland, Utility model No 40767. Patent Office Bulletin RP. 5, p. 38.

S z mańko T., Góre ck a J., Korzen i owsk a M., Mali cki A., Eremenko E. (2007). Comparison of chosen quality parameters of meat from wild boar and domestic pigs. Pol. J. Food Nutr., 57: 523-528.

W ang Q., Che n Y.J., Y o o J.S., K i m H.J., C h o J.H., K i m I.H. (2008). Effects of supplemental humic substances on growth performance, blood characteristics and meet quality in finishing pigs. Livest. Sci., 117: 270-274.

Accepted for printing 7 XI 2011

DOROTA MIŚTA, ANNA RZASA, TADEUSZ SZMAŃKO, WOJCIECH ZAWADZKI,
MARZENA STYCZYŃSKA, ANNA PINTAL, BOŻENA KRÓLICZEWSKA

Wpływ preparatu huminowo-tluszczowego na parametry produkcyjne oraz jakość mięsa królików rosnących

\section{STRESZCZENIE}

Badano wpływ preparatu huminowo-tłuszczowego na wskaźniki produkcyjne oraz jakość mięsa u królików. Materiał stanowiły króliki rasy nowozelandzkiej białej, które podzielono na trzy grupy po 8 zwierząt w każdej. Zwierzęta grupy kontrolnej były żywione standardową paszą granulowaną, grupy $\mathrm{H} 5$ - paszą z 5\% dodatkiem preparatu huminowo-tluszczowego, natomiast grupy $\mathrm{H} 10$ - paszą z $10 \%$ dodatkiem tego preparatu. Doświadczenie trwało 6 tygodni, po czym zwierzęta poddano ubojowi. W grupach doświadczalnych odnotowano wyższe przyrosty oraz wskaźniki wykorzystania paszy niż w grupie kontrolnej. Stwierdzono korzystny wpływ zastosowanego preparatu na parametry jakościowe mięsa, takie jak zawartość żelaza, twardość i kolor, jednocześnie jednak obserwowano wzrost podatności thuszczu na zmiany oksydacyjne. 